\title{
Las bases políticas e ideológicas del catalanismo de izquierdas del siglo XX
}

\author{
Pere Gabriel
}

\section{UNA INTRODUCCIÓN NECESARIA: EL CATALANISMO OCHOCENTISTA}

Los debates abiertos en el mundo político español a finales del siglo $X I X$ y posteriormente determinadas aplicaciones historiográficas efectuadas por el marxismo antifranquista de los años sesenta identificaron el catalanismo con las versiones más burguesas del mismo y entendieron su desarrollo en relación a las necesidades de una burguesía, la catalana, que no había logrado mantener una posición hegemónica dentro del estado liberal español y que no había podido imponer un modelo de desarrollo avanzado en el conjunto de la sociedad española. Se tendía por tanto, así, a la homogeneización del catalanismo y se difuminaban las diferencias existentes entre las dos líneas constitutivas del catalanismo, activas desde los años de la revolución liberal en España. Sin embargo, cualquier análisis mínimamente riguroso debe contemplar a lo largo del siglo $x \mid x$ el empuje y el mantenimiento de un importante y en determinados momentos claramente mayoritario catalanismo de izquierdas plenamente imbricado con la tradición del republicanismo federal y la articulación política de los sectores populares catalanes. Propiamente el catalanismo había partido justamente de la izquierda democrática en el contexto de la búsqueda e intentos de construcción de un nuevo estado alternativo al burgués moderado español. Si ciertamente es importante reconocer la existencia coetánea, normalmente en tensión, de las dos versiones, la de izquierdas y de tradición federal y la de derechas más inclinada a la cultura tradicional y conservadora, también es necesario percatarse de que no siempre una $u$ otra mantuvo una posición hegemónica. 
La hegemonía del catalanismo de izquierdas fue bastante clara a lo largo de los años setenta y ochenta. Durante el Sexenio en general tendió a identificarse catalanismo con la izquierda y el progresismo extremo del abanico politico. Fueron hornbres de izquierda los que acuñaron y sustantivizaron el calificativo, mientras que la cultura tradicionalista y conservadora no iba más allá de las formulaciones "provincialistas". A los hombres de derechas les era difícil autocualificarse de "catalanistas" en la medida que el catalanismo giraba alrededor de la formulación federal y progresista. Significativamente, a partir de 1873-1874 una asociación que reunió universitarios como La Jove Catalunya se deshizo y buena parte de sus miembros retornaron al conservadurismo y pretendieron justificar sus ardores extremos como una fiebre juvenil. Por otro lado, y contra la imagen más extendida y tópica, bajo la Restauración el catalanismo no quedó sólo recluido en el movimiento impulsado por Valentí Almirall (1841-1904) al romper con la disciplina pimargalliana. Almirall había mantenido posiciones explícitamente catalanistas durante el Sexenio y ya a partir de 1880 creó el Centre Català, impulsó congresos catalanistas que se querian unitarios $(1880,1883)$ aunque no pudieron evitar las reticencias y la oposición de los conservadores y, finalmente, logró encabezar la protesta del Memorial de Greuges de 1885. Pero el catalanismo de izquierdas no ha de identificarse sin más con el trabajo y el ideario almirailiano. A su lado existieron otros movimientos herederos del federalismo catalán del Sexenio como el que logró articular Josep Narcís Roca i Farreras (1834-1891), que era médico, alrededor de l'Arch de Sant Martí (en Sant Martí de Provençals, 1884-1892), que mantuvo posiciones claramente nacionalistas que identificó con la izquierda social y sus reivindicaciones. De cualquier modo, el movimiento catalanista más importante continuó siendo el de los federales. La ruptura de 1881 de Almirall no significó el abandono de su tradición catalanista. De la mano de Josep M. Vallès i Ribot (1849-1911) el federalismo continuó su proceso de articulación interna como partido y en el congreso federal de 1883 eiaboró una propuesta de constitución del «estat català» y un programa de actuación de configuración caialanista que no iba a ser superada respecto de las atribuciones demandadas hasta los años veinte en tiempos de Francesc Macià. El vallesismo fue en aquellos años ochenta un movimiento claramente catalanista - que desarrollaba el esquema federal y se apartaba de la estrategia almiralliana al negarse a disolver el partido en un movimiento interclasista. Sin duda, su fuerza popular no tenía por aquel entonces parangón. Hay que tener en cuenta que incluso dentro del anarco colectivismo las posiciones de clara catalanidad - que no catalanista lógicamente-- eran mayoritarias dentro de la dirección en 
la que hombres como Josep Llunas i Pujals, Rafael Farga Pellicer, Eudald Canibell y otros no tenían excesivos problemas en situar el desarrollo de la catalanidad como uno de los efectos del camino de la anarquía ".

Fue frente a este catalanismo que se articuló la alternativa conservadora. No es casual que las primeras formulaciones doctrinales sistemáticas de la misma no fueran, sino respuestas militantes a las elaboraciones de los republicanos. Así Mañé i Flaquer con Lo Regionalisme en 1887 o, más adelante, Torras i Bages, con La tradició catalana, en 1892, textos que polemizaban explícitamente con la literatura doctrinal básica de raíz federal y catalanista de izquierdas como Las nacionalidades de Pi i Margall (1876) y Lo Catalanisme de Valentí Almirall (1886). El mismo vigatanismo impulsado por Torras, mosén Collell y otros desde Vic, no hizo, sino renovar el tradicionalismo carlista para ofrecer una alternativa de catalanismo católico al catalanismo laico, progresista y republicano.

El ascenso y dominio hegemónico de este catalanismo conservador iba a producirse sobre todo en la década de los noventa. Fue paralelo a la consolidación del régimen de la Restauración y a la hegemonía conservadora entre las élites culturales catalanas. El nuevo catalanismo iba a aparecer como una manifestación precisamente de este nuevo prestigio de una intelectualidad catalana respetable y académica, alejada ahora de los devaneos laicistas y librepensadores. La renovada oleada conservadora iba a poner de manifiesto una envidiable capacidad para reconvertir en beneficio propio las diversas campañas políticas del catalanismo. Un ejemplo especialmente significativo en este sentido fue el de la cuestión jurídica abierta el 1889. El vallesismo inició la protesta política y se empleó a fondo, pero si su capacidad de movilización era alta su capacidad de negociación política con el sistema era prácticamente nula. Así, al final iban a ser Narcis Verdaguer i Callís y la Lliga de Catalunya quienes lograrán la denominada propagandísticamente «la primera victoria del catalanismo?

Es muy significativa la evolución institucional de este catalanismo conservador. Hay que partir de una organización, el Centre Escolar Català (con jóvenes universitarios), que en 1886 se separó del Centre Català

\footnotetext{
Cf. Pere GabriEL: Catalanisme i republicanisme federal del vuitcents, en AAVV: El catalanisme d'esquerres, Girona, 1997, Pere GABRIEL: Anarquisme i catalanisme, en AAVV: Catalanisme. Historia, Politica i Cultura, Barcelona, 1986.

2 Este sería precisamente el título del libro de Verdaguer I Callis, editado a modo de homenaje al autor en Barcelona en 1919, con prólogo de F. Maspons i Anglasell.
} 
(aquel centro de raíz federal y popular creado por Almirall) y se unió en 1887, con buena parte de la gente de "La Renaixensa" dentro de la Lliga de Catalunya. Esta Lliga asegurará sobre todo el contacto del nuevo catalanismo con el tradicionalismo y el vigatanismo. En 1891 este grupo pudo dinamizar la alternativa organizativa - conservadora- a lo que había representado el Centre Català, y creó la Unió Catalanista, especie de confederación catalana de entidades catalanistas de muy diverso signo - la mayor parte de las cuales habían mantenido relaciones con el Centre Català. Fue entonces, desde la Unió Catalanista y el vigatanismo que se establecieron, en marzo de 1892, las famosas Bases de Manresa, un texto claramente alternativo y que respondía a una tradición ideológica distinta a la constitución federal de 1873. Un grupo de jóvenes asumió de hecho el protagonismo de aquel catalanismo (los Verdaguer i Callís, Prat, Duran i Ventosa, Puig i Cadafaich, Domenech i Montaner) e imprimió su especial impronta en las principales actuaciones catalanistas del momento. La crisis de la guerra social, por último, iba a favorecer su contacto con fuerzas económicas desengañadas. De ambos sectores, de una joven intelectualidad profesional y unos representantes directos de corporaciones económicas surgirian en 1901 la Lliga Regionalista ${ }^{3}$.

He hablado de dos tradiciones bastante diferenciadas a lo largo del siglo $x \mid x$ en el nacionalismo catalán. Las dos coexistieron, con mayores - menores tensiones, pero la hegemonía correspondió a lo largo del siglo mayoritariamente al catalanismo progresista de raíz republicana y federal. Sólo a finales del siglo, digamos a partir de 1888-1889, la hegemonia pasó al catalanismo conservador. Significativamente, entonces, la extrema izquierda del abanico político - la izquierda del republicanismo, por ejemplo y la mayor parte de la dirección anarquista del movimiento obrero- empezó a proclamarse con beligerancia anticatalanista, empezó a considerar el catalanismo como la expresión de sectores burgueses y conservadores. A notar que, por el camino, triunfaba una concepción de la nación y del nacionalismo que alejaba cualquier perspectiva de voluntad revolucionaria e inter-relación entre voluntad democrática y el propio concepto de riación.

3 Como es sabido, la bibliografía en este campo es abundante. A destacar los libros clásicos de I. MolAs, La Lliga Catalana, 2 vols., Barcelona, 1972, y B. de Ricueh, Lliga Regionalista: la burguesia catalana i el nacionalisme (1898-1904), Barcelona, 1977. Últimamente, el centenario de las Bases de Manresa ha provocado diversas ediciones conmemorativas. A retener, J. TERMES y A. Colomines, Les Bases de Manresa de 1892 i els origens del catalanisme, Barcelona, 1992. Contamos ahora, por otra parte, con un detallado análisis sobre la primera etapa de la Unión Catalanista. Cf. J. LLORENS I VILA, La Unió Catalanista i els orígenes del catalanisme polític, Barcelona, 1992. 
En palabras, creo que rotundas, de Pere Muntanyola y Enric Prat de la Riba, en 1894:

\section{«P. Quines diferèncias hi ha entre l'Estat i la Patria?}

R. L'estat és una entitat política artificial, voluntària; la pàtria és una comunitat històrica, natural, necessària. Lo primer és obra dels homes; la segona és fruit de les lleis a que Déu ha subjectat la vida de les generacions humanes.

P. ¿Quin exemple de la història contemporània ha palpables aquestes diferències?

R. Lo de Polonia, L'estat polonès mori quan los exèrcits d'Austria, Rússia, Prússia l'esquarteraren; mes Polonia continuà i continua sent l'única pátria dels polonesos.

$P$. Què es, doncs, la pàtria?

R. La comunitat de gents que parlen una mateixa llengua, tenen una história comuna $i$ viuen agermanades per un mateix esperit que segella amb quelcom d'original i caracteristic totes les manifestacions de la seva vida" 4.

Basta, evidentemente, aparte de valorar la importancia de su distinción entre estado y patria, con sustituir la palabra patria por nación. Y si queremos ver el contraste con la concepción más federal y progresista, veámos lo que decía al respecto Pi i Margall en 1882:

"Ni es tampoco cierto que sean las naciones obra de la naturaleza. Se unen pueblos de diferente raza y diferente lengua, y se dividen los de una misma lengua y una misma raza. Viven juntos pueblos que se rigen por diversas leyes; $y$ separados, pueblos que obedecen a unos mismos Códigos.

El pacto ... es el espontáneo y solemne consentimiento de más o menos provincias o estados, a confederarse para todos los fines comunes, bajo condiciones que estipulan y escriben en una constitución ${ }^{5}$.

Por otra parte, erróneamente se atribuye comúnmente al catalanismo conservador de finales de siglo la asunción de la distinción conceptual más moderna entre nación y estado. De hecho, aparte que ya en Las Nacionalidades de $\mathrm{Pi}$ i Margall pueden rastrearse el tema, de manera muy explícita y rotunda Vallès i Ribot ya la formularia a mediados de 1886 . De hecho sería el catalanismo federal el que más avanzaría en esta dirección, aunque aceptase a menudo el término «región» como equivalente,

\footnotetext{
- 4 P. Montanyola y E. Prat de la Riba, Compendi de la Doctrina Catalanista, Sabadeli, 1894

5 F. PI I Margall, Las nacionalidades, 3. ${ }^{a}$ edición, Madrid, 1882, Apéndice 5. El pacto, págs. $435-436$.
} 
en aras de su uso coetáneo más extendido, y tendiese a aceptar el término nacionalidad y nación como equivalente a estado.

\section{LA EVOLUCIÓN POLITICA: PARTIDOS, GRUPOS Y COALICIONES, 1900-1936}

Lerroux y el triunfo del liberalismo-progresista, de afirmación española, en la izquierda

El panorama de la izquierda catalana al empezar el siglo aparece extraordinariamente fragmentado, dominado, eso sí, por la vigencia de una cultura política republicana, ahora más decantada hacia la tradición ideológica del liberalismo progresista en contraposición a la hegemonía que había existido de la iradición federal liberal democrática. Un buen ejemplo parte de la preparación de la candidatura de las legislativas de 1901, las elecciones que representaron el éxito de la Lliga Regionalista en Barcelona ${ }^{6}$.

Un manifiesto común (incluyéndose los federales) fue firmado el 14 de febrero de 1901. Firmaban los de Fusión Republicana, que se había estabilizado como partido en 1899 bajo la referencia de Salmerón, aunque muchos procedían del viejo posibilismo. Estaban allí Emili Junoy, Eusebi Corominas, un joven Francesc Layret. Su órgano era "La Publicidad" -el veteranísimo órgano de los posibilistas catalanes. Después estaban los progresistas, que en Cataluña aparecían ahora dominados por el viejo progresismo respetable (y mucho menos el zorrillismo plebeyo y escandaloso), con Eusebi Jover i Josep Antoni Mir i Miró. Flirteaban con los de Fusión, pero mantenian la obediencia más o menos formal respecto del Dr. Esquerdo. Al lado de estos dos digamos partidos, había una considerable relación de centros y núcleos autotitulados independientes. Destacaban en ese sentido los del Centre Republicà de la calle de Rarnalleres (que seguía a Joan Sol i Ortega y Ramón Codina, otro exprogresista), los independientes de la Fonda "El Siglo" encabezados por el aragonés Lorenzo Ardid y por Tiberio Ávila, así como multitud de

\footnotetext{
6 Como es sabido aquellas elecciones reportaron la primera quiebra del sistema dinástico en la ciudad de Barcelona, donde se produjo el triunfo por las mayorias de la Lliga Regionalista que logró la victoria de los "cuatro presidentes": Bartomeu Robert -expresidente de la Sociedad Económica de Amigos del Pais-; Albert Rusiñol —expresidente del Fomento del Trabajo Nacional-; Lluis Domenech i Montaner —expresidente del Ateneu Barcelonés-; Sebastià Torres presidente de la Liga de Defensa Industrial y Mercantil. Por la minoria, signo de una nueva época, venció Alejandro Lerroux al lado de Fi i Margall. Los dinásticos sólo lograron intercalar a Pere G. Maristany, liberal.
} 
notables al estilo de Odón de Buen, Joan Pla i Mas, Josep M. Serraclara, Cristóbal Laban y muchos otros.

A su lado, también firmantes del manifiesto, estaban los federales de Vallès i Ribot. Con Francesc Pi i Arsuaga, Antoni Ferrando, Conrad Roue, Joaquim Viñas i Pagès, Miquel Vilà, Francesc Pi i Sunyer, una vieja guardia, que aparecería sólo momentáneamente unida. Vallès, a la muerte de $\mathrm{Pi}$, iba a romper pronto con Eduardo Benot y los federales catalanes renunciarían de hecho defintivamente a la inserción en la dinámica de la izquierda española. Hay que tener en cuenta que los federales eran, ya a principios del siglo, los grandes perdedores ante la emergente hegemonía del catalanismo conservador en la medida que habian sido ellos, y de hecho sólo ellos, los que habían mantenido un catalanismo de intervención política y relación española a lo largo de la Restauración del ochocientos. El hecho tenía mucha significación en la medida que implicaba la desintegración y crisis de una cultura política republicana que en Catalunya había sido bastante distinta de la de tradición liberal progresista del resto de las familias republicanas y que se había movido en conjunto bajo unas coordenadas ideológicas de un liberalismo democrático y federal, obrerista y socialista.

No se trata ahora de detallar el impacto causado por el aterrizaje de Lerroux en Barcelona, explicado mucho y bien (por Culla y Álvarez Junco ${ }^{7}$ ). Un Lerroux que llegó de la mano del republicanismo progresista y que vino a revitalizar, articular y en parte al menos sancionar la hegemonía de aquella cultura liberal progresista, a la que ahora dotada de discursos, acentos y agitación populistas. A destacar que la gran labor organizativa de Lerroux a través del impulso de la Fraternidad Republicana implicaba la movilización y articulación de núcleos e instituciones de todo tipo (y había muchas ya existentes) como escuelas, cooperativas, centros de francmasonería, asociaciones feministas, grupos ácratas, etc.

\section{La UFNR y la izquierda catalanista}

El desconcierto federal iba a facilitar la marcha hacia otros movimientos y prácticas catalanistas de muchos republicanos, en especial los federales (otros se sumarian a la Unión Republicana mitad salmeroniana, mitad lerrouxista de 1903). A recordar como ejemplos muy significativos que la primera Lliga Regionalista pretendía actuar como un movimiento no

Cf. Joan B. Culla (1986): El republicanisme lerrouxista a Catalunya (1901-1923), Barcelona, y Álvarez Junco (1996): Alejandro Lerroux, el emperador del Paralelo, Madrid. 
necesariamente derechista (se hablaba así del "neutralisme regionalista») y reunió republicanos destacados como el exposibilista Ildefons Sunyol, el ex-federal Joaquim Lluhí i Rissech y nacionalistas pro-republicanos como Jaume Carner. De la situación de principios de siglo se dibujaron dos caminos catalanistas de la izquierda: el derivado del catalanismo de izquierdas que se había unido a la Lliga y que se movía alrededor de movimientos ya más veteranos como los de la Unión Catalanista; y el derivado de los restos más orgánicos del partido federal.

La visita del rey el 1904 como es sabido rompió la Lliga: la izquierda marchó y recogió de hecho todos aquellos grupos y movimientos de tradición federal y catalanista. Marcharon Stinyol i Carner, más Giralt i Pijoan; el ex-federal Lluhí i Rissech, el periodista Frances Rodón. (También coyunturalmente Ventosa i Calvell y Domènech i Montaner, que pronto retornarían). Fue el grupo que dinamizó primero el semanario «El Poble Catalá» el noviembre de 1904 y posteriormente diario (a partir del uno de mayo de 1906 en plena campaña de Solidaritat Catalana). Al margen de múltiples colaboraciones independentes (el mismo Maragall, d'Ors) los hombres de «El Poble Català fueron Sunyol, Carner y Lluhí. El periódico, con un papel muy especial de Lluhí i Rissech se empeñó en la formulación de un catalanismo de izquierdas (frente a las críticas que partían de la "otra" cultura republicana liberal progresista (Lluis de Zulueta por ejemplo) que negaba toda posibilidad de un catalanismo de izquierdas ${ }^{8}$. El debate situado alrededor de las elecciones de 1905 tuvo incluso su reflejo en el campo anarcosindicalista. Donde también dominaba ahora la identificación entre catalanismo y versión conservadora. Allí, "El Productor" permitió una serie de artículos en catalán de Mas-Gomeri que reivindicaba el catalanismo de la izquierda, ácrata, frente a la derecha a los que justamente acusaba de no ser catalanistas.

De forma paralela, la catalanización de los federales se agudizó a la muerte de $\mathrm{Pi}$. A principios de 1905 llegó la definición catalanista, acompañada de la ratiticación de una lectura sociaiista del programa federal de 1894, efectuada por el Consell Regional Federal Català. Siguió la ruptura con la Asamblea Federal reunida en Madrid el 16 de mayo de 1905. De momento sólo un pequeño grupo de dirigentes catalanes siguió la obe-

8 Zulueta, en polémica con Lluhí i Rissech, empeñado en conducir el catalanismo de nuevo hacia la izquierda, había mantenido que no existía un catalanismo de izquierdas, sino una derecha catalanista ("políticamente, todo el nacionalismo catalán es reaccionario" había escrito, y añadia "no espero que exista jamás un catalanismo radicalmente democrático"). Cf. "La Publicidad", 26 de noviembre cle 1905. 
diencia de Eduardo Benot. Aunque su decadencia organizativa iba a ser cada vez mayor. Los federales lograrían cuatro diputados en las elecciones legislativas de septiembre - a las que acudieron en alianza con los de Unión Republicana-, pero ante las municipales del mes de noviembre en Barcelona se presentaron solos y no obtuvieron ninguna concejalía.

Pronto iba a llegar un tercer elemento de revitalización del catalanismo de izquierda. Fue el derivado de la formación del pacto de Solidaritat Catalana. No repetiré aquí su origen, en relación a la crisis de autoridad ante los militares de los gobiernos dinásticos. Fue firmado en enero de 1906 y reunió en un principio la práctica totalidad de las fuerzas políticas activas en Catalunya; quedaron fuera los dinásticos alfonsinos. Ya sabemos que el pacto iba a significar la ruptura interna de los republicanos, la protesta del lerrouxismo y la final formación del Partido Radical en enero de $1908{ }^{9}$. Lo que importa ahora es constatar que dentro del movimiento solidario se reunieron fuerzas de la izquierda que provenian de la Unión Republicana y no siguieron a Lerroux. También que hubo una serie de independientes que reencontraron la actividad política a través del movimiento (como Hurtado). Aquellos unionistas e independientes republicanos solidarios iban a ser una tercera fuerza de la revitalización del catalanismo de izquierdas. Un ejemplo sintomático puede ser el del mismo Lluis de Zulueta que acababa de negar la posibilidad de un catalanismo de izquierda y ahora era solidario ${ }^{10}$.

En aquel contexto, fue creado el Centre Nacionalista Republicà (CNR) el 22 de diciembre de 1906 a partir del grupo de «El Poble Català». Se autoproclamaba «un partit d'esquerra liberal» al que algunos pretendían

\footnotetext{
9 En el Comité Ejecutivo de Solidaritat Catalana estaban Martí i Julià en nombre de la Unió Catalanista, Vallés i Ribot por los federales, Jaume Carner del Nacionalisme Republicà, Amadeu Hurtado como independiente, al lado de Francesc Cambó de la Lliga i Miquel Junyent que representaba a los carlistas. La división republicana, ante el apoyo ofrecido por Nicolás Salmerón se oficializó en la Asamblea General de la Unión Republicana reunida en Madrid el 23 de junio de 1907. Lerroux logró un indudable éxito en Barcelona. Creó "El Progreso" que apareció a partir del 29 de junio de 1906 y logró que unos dos tercios de los militantes de la UR (y la práctica totalidad de las entidades que adherían UR) rompieran con Solidaritat Catalana. Incluso contó con el apoyo de algunos exfederales como Jaume Anglés, Joan Lladó i Vallés (sobrino de Vallés i Ribot) o Pau Barbé i Huget.

10 Unionistas solidarios fueron, entre otros, el abogado Francsc de P. Roqué, los periodistas Josep Roca i Roca, Eusebi Corominas, Ildefonso García del Corral y Emili Junoy, el abogado y catedrático de Instituto Manuel Pereña, leridano, el economista Josep Zulueta, sempieterno diputado a cortes por Vilafranca, el catedrático de Universidad Odón de Buen, aragonés, los abogados Albert Bastardas, Joan Moles, Antoni Marsà, Francec Layret, Laureà Miró, etc. En conjunto, una buena muestra de la plana mayor y más política de la Unión Republicana que aceptaba la dirección de Salmerón y que provenia en buena parte del viejo posibilismo.
} 
llamar también "socialdemócrata». Los hombres fuertes del nuevo grupo eran Jaume Carner (1867-1934), Joaquim Lluhì i Rissech (1866-1929), e Ildefons Sunyol (1866-1913). Pero contaban también con una extensa nómina de jóvenes intelectuales y profesionales (Antoni Rovira i Virgili, Josep Pou i Pagès, Gabriel Alomar, Claudi Ametlla, Màrius Aguilar, Ignasi Iglesias, Joaquim Casas i Carbó). A su vez, las juventudes republicanas impulsaron un movimiento de aproximación de los diversos grupos en el congreso catalán de 18-20 de abril de 1908, que contó con la participación de las juventudes del Centre Nacionalista Republicà (CNR), los federales, la Unión Republicana y la Unión Catalanista. Allí, dónde iba a destacar Francesc Layret (1880-1920), que presidió, fue clara la intervención de la izquierda solidaria.

El proceso de unión de la "esquerra catalana" primero y la formación de la UFNR (la Unió Federal Nacionalista Republicana) fue relativamente claro en 1909-1911. Por un lado, en el CNR desde últimos 1908 Lluhí i Rissech, y Sartiago Gubern de las juventudes, promovieron el abandono de Solidaritat Catalana, disconformes con la dirección práctica de Francesc Cambó y los pactos de éste con Antonio Maura. A su vez, la no reelección de Carner facilitó el ascenso de Lluhí al frente del CNR (16 de enero de 1909). Su política era la de la unión de las fuerzas republicanas de Barcelona y Cataluña. Iba a lograr el apoyo de la junta municipal de Barcelona de la UR (Francesc Layret i Albert Bastardes), así como la de los federales (Vallès, Roig i Armengol, Laporta, Tona, Salvatella). Los éxitos relativos electorales de 1909 en Barcelona de una llamada «Entesa d'Esquerra Catalana» en las elecciones municipales (cuando obtuvieron 8 concejales, muy por debajo de los 16 radicales, pero muy por encima de los resultados de la Lliga que sólo obtuvo 4) terminaron por facilitar el proceso de unificación de aquella izquierda catalanista.

La consolidación en direcciones complementarias de los radicales y la nueva "Esquerra Catalana" fue también clara en las provinciales de octubre 1909. Los candidatos de la izquierda ganaron de nuevo en Barcelona (13 radicales, 7 de la Esquerra Catalana y 5 de la Lliga).

Es un tópico cierto el de la débil profesionalidad política de aquel catalanismo de izquierdas. Como en los otros grupos estables la práctica totalidad de sus dirigentes eran hombres de profesiones liberales y muy en especial abogados y estaban en la política siempre dudando entre su papel profesional (al que dotaban sin duda de una función social) y el papel más exclusivamente político. Así fueron produciéndose una serie de retiradas. Primero hubo las de Sunyol y Carner (en 1908 a los 42 años Sunyol y los 41 de Carner). Lluhí (también de 42 años) estaba maldotado para la imagen 
pública y además su salud era también mala. No quería ir a Madrid. Al final, ante este panorama, el partido optó por Pere Coromines (1870-1939) como dirigente (era el director del periódico desde noviembre de 1909), aunque fue aún Lluhí, en su último acto político dirigente, quien obtuvo la unificación en enero de 1910. Se unieron efectivamente el CNR, la UR y el partido federal. Sólo quedaron fuera algunos progresistas y, obviamente, los lerrouxitas del Partido Radical. El nuevo partido nació con la voluntad de entendimiento entre los distintos términos de la denominación, que fue muy discutida y explícitamente defendida. Una extensa conferencia de Corominas pronunciada en el Teatro Novedades el 6 de marzo de 1910 propugnaba un federalismo nacionalista; Vallès no quería renunciar al federalismo, ni Lluhí al nacionalismo. De ahí la denominación adoptada de Unió Federal Nacionalista Republicana. Las Bases fueron redactadas por Vallès, Junoy, Corominas (que refundieron en una buena parte el programa federal de 1894). Fueron firmadas el 1 de abril de $1910^{11}$.

La evolución posterior fue difícil. Participó en la Conjunción Republicana/Socialista, a partir de febrero de 1911 cuando rompió con los radicales. Iban a activarse, sin embargo, múltiples tensiones alrededor de la mayor o menor compromiso con el catalanismo, con el republicanismo catalán y con la izquierda española. Algunos dirigentes eran proclives al pacto con los radicales y la política de "Catalunya endins» (Lluhí, Gubern), otros lo eran a la política española (Layret). Corominas y Carner, en medio, andaban indecisos. En este contexto, el empuje del reformismo de Melquíades Álvarez a partir de 1912 debilitaría enormemente la UFNR. La apuesta de Melquíades Álvarez, que rectificó antiguos españolismos unitaristas, logró el apoyo de no pocos republicanos que provenían del anterior posibilismo, de la Unión Republicana y de la misma "Publi» (en especial Josep Zulueta, Laureà Miró, Emili Junoy, y Lluís Companys, García del Corral, Lluís de Zulueta), al lado de algún ex-radical (Tiberio Ávila, por ejemplo). En la coyuntura de 1912-1913, el reformismo catalán iba a reunir a los que creían en la necesidad de una política hispana, considerada más eficaz que no el repliegue catalán si se trataba de avanzar en la obtención de cotas autonómicas. Los fracasos electorales de 1913 terminaron por forzar el pacto republicano de la UFNR con los radicales (denominado «Pacte de Sant Gervasi”), el 6 de febrero de 1914, que generó una crisis prácticamente definitiva iniciada por la dimisión en pleno de la redacción de «La Publicidad".

\footnotetext{
11 Firmaron en nombre del CNR, Carner, Sunyol, Lluhi, Gubern y Coromines; en nombre de la UR, Cormines (Eusebi), Miró, Junoy, Bastardas, Layret y Álvarez; en nombre de los federales, Vallès, Miquel Laporta, Juli Marial, Roig i Armengol, Conrad Roure.
} 
¿Quienes eran los nuevos republicanos catalanistas del Centre Nacionalista Republicà, "El Poble Català" y los restos del PRDF, que habían intentado la UFNR? Lo hemos visto: profesionales. Quizá de forma más sig. nificativa deberiamos añadir que sus votantes y militantes se encontraban entre los trabajadores y sectrores con perspectivas de estabilidad social y enraizamiento ciudadano pausado. Estaban en la Barcelona estable que llenaba la geografía "central" de la ciudad; mientras que el lerrouxismo tendía hacia las periferias más inestables (el Pueblo Seco, el Pueblo Nuevo, la Barceloneta, etc.). Su apuesta política fue especialmente compleja y difícil, especialmente abierta hacia el socialismo democrático y el socialismo liberal. Pretendieron la recuperación y renovación de la cultura progresista del ochocientos y quisieron obsesivamente encontrar un referente laborista. Frente a la insistencia historiográfica en la definición como movimiento con formas políticas modernas respecto del lerrouxismo, sería útil fijarse ahora en la mayor complejidad y apuestas políticas de futuro que representó el catalanismo de izquierdas de la UFNR ${ }^{12}$.

Los años de la primera guerra y la dispersión de la izquierda. El obrerismo militante arrincona el republicanismo catalanista. La Unión Socialista de Catalunya

El fracaso de la UFNR como aglutinador de un catalanismo de izquierdas de definición republicana iba a encontrarse a lo largo de los años de la guerra con un nuevo frente: el de la revitalización y articulación obrera a través de la CNT ( $y$ en parte una cierta revitalización del PSOE, aunque ésta aparezca oscurecida ante la visibilidad del anarcosindicalismo).

Un primer grupo que pretendió recoger aquella herencia fue la Esquerra Nacionalista formada en junio de 1914 por una parte de los ex-redactores de "El Poble Català" que se aglutinaron alrededor de Antoni Rovira i Virgili y bajo el lema de "Catalunya endins", pretendieron animar la acción de las clases medias catalanas y actuar al margen del republicanismo español. El grupo no llegó a cuajar como partido y de hecho a partir de enero de 1915 iba a subsımirse en ia aventura socializante de la vieja Unión Catalanista ahora dirigida por el doctor Domènec Martí i Julià (18611917).

12 Las mejores referencias sobre este grupo se encuentran en el buen estudio de KLAUS-JüRGEN NAGEL (1991): Arbeiterschaft und nationale Frage in Katalonien zwischen 1898 und 1923, Saarbrücken-Fort Lauderdale. 
Mayor consistencia tendría la formación del Bloc Republicà Autonomista [BRA] el 6 de mayo de 1915 que impulsó Francesc Layret y logró el concurso de Marcel.lí Domingo, Santiago Valentí Camp, Gabriel Alomar, el ya viejo y respetable Conrad Roure, David Ferrer y Ángel Samblancat. Su manifiesto inaugural intentaba profundizar por la izquierda el programa de la extinta UFNR. Se aceptaba explícitamente una perspectiva socialista y se decía ser un partido de izquierdas de la clase obrera. Estaban dispuestos a colaborar con los socialistas y los republicanos del resto de los pueblos de España. Apostaban por una República Federal Española en la que cupiesen tanto los nacionalistas catalanes más radicales como los más autonomistas. El grupo al lograr la incorporación en abril de $1917 \mathrm{del}$ republicanismo catalanista leridano (Alfred Pereña y Humbert Torres) pasó a denominarse Partit Republicà Català [PRC]. El nuevo partido supo reunir el republicanismo más activo que había actuado disperso y fraccionado a raíz de la dispersión de 1913-1914. Obtuvo asi el apoyo de ex-reformistas (Companys, Bernaldo de Quirós), ex-UFNR y ex-Federales (Isidre Rius de Vilafranca o August Pi i Sunyer de l'Empordà por ejemplo). Su órgano de prensa fue "La Lucha", que dirigiria Marcelino Domingo (Companys fue el redactor jefe) y que tanto protagonismo iba a adquirir a raíz de su papel en la crisis del verano de 1917. El PRC vino así a continuar la UFNR, aunque ahora, signo de los nuevos aires sindicales que estaba imponiendo la realidad de la guerra europea, aquel republicanismo apareciese obsesionado en convertirse en un portavoz político de la clase obrera 0 , al menos, actuar como correa de transmisión política del sindicalismo, al modo del laborismo británico.

En la misma línea, debe situarse la Unió Socialista de Catalunya [USC] que se constituyó el mes de julio de 1923 mediante la confluencia de hombres procedentes del catalanismo liberal (Gabriel Alomar, Rafael Campalans, Manuel Serra i Moret), socialistas del PSOE (Josep Comaposada), Cristòfol de Domènec, Alfons Maseras, algún sindicalista (Joan Fronjosà, Manuel Escorsa). Algunos de sus adherentes eran gente del mundo de la cultura que no había tenido una participación política militante (como Feliu Elias, Carles Fages, Emili Mira, Cosme Rofes). El órgano de prensa sería "Justicia Social" (3 de noviembre de 1923-1 de mayo de 1926) ${ }^{13}$. La USC en su primera etapa pretendió la articulación de un socialismo explícitamente reformista, de contenido intelectual y liberal, muy respetuoso con la labor de los fabianos ingleses y del socia-

13 La revista se consideró heredera de "La Justicia Social", que habia aparecido en 1909 y habia sido el órgano de la federación catalana del PSOE en 1910-1916. "Justicia Social» iba a reaparecer el julio de 1931, instaurada ya la Segunda República. 
lismo francés de Jean Jaurès. Aspiraba, además, a mantener una clara autonomía catalana, al margen de las direcciones y los partidos españoles, confiaba de algún modo en actuar como referente posibilista y político del movimiento sindical ${ }^{14}$.

La quiebra catalanista de la Lliga: el catalanismo intelectual y señor de la Acció Catalana

La Conferencia Nacional Catalana se reunió los días 4 y 5 de junio del 1922, convocada por las juventudes de la Lliga Regionalista, la Joventut Nacionalista. Reunió el nacionalismo catalán más radical, que había exacerbado posiciones alrededor de las discusiones derivadas de la campaña de autonomía de 1918-1919 y la crítica a la política considerada simplemente "española" de la Lliga Regionalista. En especial, al lado de una serie de dirigentes jóvenes de la Lliga, con una alta presencia del mundo profesional e intelectual, estuvieron presentes algunos núcleos republicanos que se encontraban sin partido y, notablemente, el grupo de la Federación Nacionalista Democrática de Francesc Macià. La discusión se centró en cual debía ser el objetivo básico del nacionalismo: la consecución del "Estat Català" (como animaban los seguidores de Macià y algunos otros) o simplemente la nacionalización de Cataluña (a través de campañas de Catalunya endins), accidentalista respecto del régimen a construir. Los macianistas se retiraron y constituyeron un nuevo grupo que pasaron a denominar Estat Català. A su vez la mayoría constituyó una entidad que llamaron de Acció Catalana, bajo la presidencia de Jaume Bofill i Mates, y un papel destacado de Antoni Rovira i Virgili y Lluis Nicolau d'Olwer ${ }^{15}$. El nuevo grupo, que se situó claramente en un contexto de catalanismo liberal y que compartía cultura política con la Liga, vio frustrada su expansión a raíz del advenimiento de la Dictadura de Primo de Rivera en 1923 aunque contó con un órgano de expresión

14 La bibliografía sobre la Unió Socialisia de Catalunya y sus hombres es abundante. A destacar; J. L. Martin Ramos (1973): "La Unió Socialista de Catalunya", en "Recerques", Barcelona, núm. 4; Jesús M. RODÉs (1976): «Socialdemocràcia catalana i qüestió nacional (1910 1934), en "Recerques", Barcelona; Albert BALCELLS (1985): Rafael Campalans, socialisme català: biografia i textos, Barcelona; Mercè BARCELO (1986): El pensament polítici de Serra i Moret. Barcelona; Ricard Alcafaz (1987): La Unió Socialista de Catalunya. Barcelona. Con mayor interés respecto de la etapa republicana, Miquel Caminal (1984): Joan Comorera (catalanisme $i$ socialisme), 2 vols., Barcelona. Recientemente. AAVV (1999): 75 aniversari. Unió Socialista de Catalunya, Barcelona.

15 Cf. en especial Jordi Casassas (1980): Jaume Bofill i Mates (1878-1933), Barcelona, y Montserrat Baras 9184): Acció Catalana 1922-1936, Barcelona. 
notable y alto significado cultural, "La Publicitat». Reunió una opción profesional y de clases medias que se querian respetables y cultos, que se autoatribuían un destacado papel director en el desarrollo de una obra nacionalizadora de la sociedad catalana.

De nuevo el catalanismo plebeyo. La ERC

La creación de la Esquerra Republicana de Catalunya ante las elecciones de abril de 1931 vino a recuperar la línea de la UFNR, favorecida por la revitalización republicana y catalanista de oposición a la Dictadura de Primo de Rivera. Sus orígenes más inmediatos se encuentra en el comíté de enlace entre los tres partidos republicanos de 1930 (Parti Republicà Català, Acció Republicana de Catalunya y Partit Republicà Democrátic Federal). A su lado estaba Estat Català (separatista e insurreccional), así como multitud de núcleos y centros y muy en especial el grupo socializante de "L'Opinión" (de Lluhí i Vallecà, el hijo de Lluhì i Rissech) ${ }^{16}$. Este grupo lanzó el Manifest d'Intel.ligència Republicana en mayo de 1930 (firmado por republicanos de izquierda, socialistas de la USC, PCC, anarcosindicalistas de la CNT y Estado Federal. La conferencia de unificación, celebrada el 17-19 de marzo de 1931, reunió el PRC, el grupo de "L'Opinió" y Estat Català. Fallaron a última hora los federales (Abel Velilla) que aceptaron la obediencia del Consejo Nacional Federal en marzo de 1931 (y no siguieron, por tanto, la línea de la Extrema Federal generada en Madrid con Joaquim Pi i Arsuaga, Enrique Bernaldo de Quirós y Eduardo Barriobero). El programa de la nueva Esquerra Republicana de Catalunya [ERC] hablaba de la "personalitat nacional de Catalunya", la "federació amb els altres pobles ibèrics", "drets de l'home i el ciutadà", "solicització de la riquesa a benefici de la col.lectivitat". Los de "L'Opinió" fracasaron en su intento de denominar el grupo "Partit Republicà Socialista". Posteriormente, su éxito electoral iba a promover la paulatina entrada de la gente de ACR.

A su lado, heredera del catalanismo de izquierdas se situó una reconstruida Unió Socialista de Catalunya, reforzada en 1930 con el ingreso de algunos ex-cenetistas como Felip Barjau o Ramon Jové, aunque los principales dirigentes continuarían siendo de momento Alomar, Campalans y Serra Moret.

16 Cf. Joan B. Cull.A (1977): El catalanisme d'esquerra (1928-1936), Barcelona. 
Sin duda la tradición del catalanismo de izquierdas y del viejo federalismo iba a situarse alrededor de Esquerra Republicana de Catalunya ${ }^{17}$. La coalición de partidos, centros y entidades que habian ganado en las elecciones de 1931, supieron, con cierta originalidad, construir una especie de partido de partidos y grupos al que dotaron en términos relativos de una alta estabilidad organizativa. La dirección de Barcelona supo pactar con multitud de centros dispersos en la geografía y complementar, desde el poder de la Generalitat, sus actuaciones más localistas y autónomas ${ }^{18}$.

La ERC mantendría, sin embargo, y un poco a grosso modo sus tres corrientes constitutivas a lo largo de los años republicanos. Por un lado estaban los que venían de Estat Català y el separatismo, con ciertos brotes de parafascismo que les llevaban a defender la idea de la unidad nacional construida bajo la dirección del gobierno y el partido, un movimiento obrero subordinado a la causa nacional y la militarización de las juventudes (los escamots de Estat Català). Actuaban en este ámbito hombres como Ventura Gassol, Josep Dencàs, Miquel Badia, en parte el mismo Jaume Aiguader, etc. El núcleo central del movimiento de ERC lo constituían, sin embargo, los republicanos catalanistas, que habian intentado la aventura de la UFNR y el Partit Republicà Català y ahora estaban atrayéndose de manera inevitable el catalanismo más centrista de Acció Republicana Catalana y del Partit Catalanista Republicà (la ex Acció Catalana). En este marco el abanico de dirigentes iba desde Lluis Companys (Domingo pronto abandonaría la Esquerra para encabezar sin ambigüedades el Partido Radica-Socialista), Joan Casanovas o Amadeu Aragay hasta gente como Pere Coromines, Rovira i Virgili, Lluís Aymamí, Carles Pi i Sunyer, etc. que firmaron la adhesión a Macià en carta de 22 de octubre de 1932). La atracción se ejercía también respecto de los medios obreristas (con algunos ex-cenetistas como Pere Foix, J. Grau Jassans, Martí Barrera, Simó Piera, Sebastià Clara, etc.) e incluso respecto de algunos comunistas (Jaume Miravitlles, Daniel D. Montserrat).

Una tercera tendencia de difícil encaje fue, finalmente, la del grupo de "L'Opinió". Al constituirse formalmente el Parlament de Catalunya y llegar

Cf. Anna Saltés (1986): Quan Catalunya era d'Esquerra. Barcelona; M. Dolores IVERN (1988, 1989): Esquerra republicana de Catalunya (1931-1936), 2 vols., Barcelona.

18 Cf. el brillante análisis introductorio de Isidie MOLAS (1999): Estatuts dels partits politics catalans, 1931-1936, Barcelona. Continúa siendo útil, por otra parte, la panorámica del mismo autor (1972): El sistema de partits politics a Catalunya (1931-1936), Barcelona. 
la hora de un primer gobierno de la Generalitat monocolor, lo presidió inicialmente Joaquim Lluhí i Vallescà (como primer conseller), pero pronto se enfrentó a Macià y resultaron excluido él y los suyos tanto del Gobierno como del mismo Partido (7 de octubre de 1933). Se llegó así a la constitución de un Partit Nacionalista Republicà d'Esquerra (15 de octubre de 1933) que contó, al lado de Lluhí, con Joan Casanellas, Antoni Xirau Palau, Joan Terradellas, Martí Feced, Joaquim Ventalló, Quero Morales, etc. Aquel PNRE criticaría con dureza el predominio de los hombres que provenian de Estat Català y las juventudes fascistizantes. Ante las elecciones de noviembre del mismo año impulsó, frente a ERC, una Coalició d'Esquerres con Acció Catalana Republicana y otras fuerzas de centro (Acción Republicana, Partit Republicà Radical-Socialista). Pero, muerto Macià, la Coalición y los lluhins pactaron con Esquerra ante las municipales de enero de 1934 y sus dirigentes entraron en el gobierno de coalición republicana que formó Lluís Companys.

En la frontera con la izquierda, el Partit Catalanista Republicana heredero de Acción Catalana, tras los fracasos electorales de abril y junio de 1931 quedó marginado de la escena política a pesar de contar con Nicolau d'Olwer como ministro de Economía en el Gobierno de Madrid y un conseller (Carrasco i Formiguera en el govern de la Generalitat). Una parte de sus militantes más conocidos se apuntaron al carro vencedor de Esquerra Republicana a la que aportaron tanto una cierta eficacia profesional como un acento moderado y respetable (Carles $\mathrm{Pi}$ i Sunyer, Josep Sunyol, Rovira i Virgili). Por la derecha también se produjeron fugas notables, en este caso hacia la organización democráticocristiana Unió Democràtica de $\mathrm{Ca}$ talunya (como Lluis Vila i Abadal, el mismo Carrasco i Formiguera) o incluso hacia la Lliga (Ramon d'Abadal, por ejemplo), pero esto es otra cuestión. La hemorragia del PCR se detuvo hacia 1933 cuando pasó a denominarse Acció Catalana Republicana y logró consolidarse como un partido de cuadros, minoritario, pero con una fuerte irradiación en la opinión culta a través de "La Publicitat" (que editaba unos 40 mil ejemplares diarios). Se situó ya sin ambages en una opción de centro dispuesto al pacto con la izquierda republicana española. Entró en la coalición frente populista de 1936 (el Front d'Esquerres de Catalunya) y obtuvo así cinco diputados, entre ellos los máximos dirigentes Lluis Nicolau d'Olwer, Claudi Ametlla y Martí Esteve.

La hegemonía de la ERC tuvo también unos efectos indirectos importantes en la resituación ante el catalanismo de las tradiciones republicanas de izquierda más tradicionales. Como es conocido, la fundación del Partido Radical-Socialista tuyo un punto de arranque importante en Cataluña y la voluntad de Marcelino Domingo, especialmente enraizado en Tortosa y 
las comarcas del Ebro. Experimentó múltiples escisiones y al final en septiembre de 1933 se produjo la definitiva ruptura en dos alas: Félix Gordon Ordás, partidario de la alianza republicana y la ruptura con el socialismo que terminó coincidiendo con la facción radical de Martínez Barrio; Marcelino Domingo y Álvaro de Albornoz, partidario de mantener la coalición republicana-socialista, que llevó el grupo a la nueva Izquierda Republicana, unificándose con el grupo de Azaña y el grupo gallaguista del ORGA. Como hemos visto, Marcelino Domingo provenía de la tradición del Partit Republicà Catalanista y había intervenido en la fundación de Esquerra Republicana en 1931. El radical-socialismo catalán tuvo así vínculos estrechos con cierta tradición catalanista que no parecía diferenciarse demasiado de las posiciones de la ERC y que se mantenía alejado de la misma más bien en cuanto se trataba de un partido de viejo estilo muy ligado a la personalidad y red de influencia local de Marcelino Domingo.

La importante tradición federal catalana había desaparecido en la medida que había alimentado los programas de toda la izquierda. En 1930 el Partido Republicano Democrático Federal [el PRDF] habia participado en el comité de enlace de fuerzas republicanas contra la Dictadura y a Cataluña llegaron en parte de efectos de la escisión surgida en Madrid que llevó a la creación de la Extrema Esquerra Federal con Eduardo Barrionuevo y el hijo del fundador, Joaquim Pi i Arsuaga. Ante la República, la dirección oficial que en Cataluña llevaba Abel Velilla era partidaria de la alianza de los republicanos incluido el partido radical, aunque mantuvo una relación preferente con la ERC, desde posiciones socialmente reformistas. Por su parte, la Extrema Esquerra Federal pretendió situarse a la izquierda de Esquerra y actuar como portavoz del anarcosindicalismo. De todas formas este bloque revolucionarista apareció dividido en pequeños grupos y facciones, notablemente alrededor de Antonio Jiménez y del capitán Medrano o del histórico Ángel Samblancat y una multitud de siglas y centros enfrentados entre sí ${ }^{19}$.

Uno de los fenómenos más peculiares de los años republicanos fue el de la configuración de un catalanismo socialista y comunista que iba a confluir, no sin tensiones, con el socialismo y el comunismo ortodoxos y que se mantuvo paralelo al preexistente comunismo procatalanista. Del núcleo de Estat Català, un sector encabezado por Jaume Compte se negó a entrar en la Esquerra Republicana en 1931 y mantuvo su nacionalismo

19 Recientemente los diversos grupos politicos que reclamaron la herencia del PDRF durante los años republicanos en Cataluña ha sido estudiado por Isidre MoLAs (1999): El partit "Extrema Izquierda Federal", Barcelona. 
radical y un fuerte radicalismo social que le llevó a constituir un nuevo grupo, Estat Català-Partit Proletari en noviembre de 1932, y finalmente un Partit Català Proletari en enero de 1934. Sus efectivos provenían del CADCl, es decir del Centre Autonomista de Dependents del Comerç i la Industria, y sus dirigentes fueron, al lado de Compte (muerto durante los hechos de octubre de 1934), Pere Aznar y Artur Cussó. Este grupo, minoritario, iba a confluir posteriormente con la Unió Socialista de Catalunya, la cual experimentó un acusado proceso de estructuración política y marxisticización de la mano de Joan Comorera (1894-1958), quien se hizo cargo de la Unión, primero como responsable de la organización (mientras Serra i Moret y Rafael Campalans se ocupaban de las actividades parlamentarias) y a partir de 1932 como nuevo secretario general ${ }^{20}$. Comorera pronto situó el debate en el terreno de la necesidad de unificación de las fuerzas marxistas y obreras. Tras un primero fracaso, en 1933, de aproximación a la Federación Catalana del PSOE, ahora en manos de Rafael Vidiella, Víctor Comomer, Desideri Trilles, etc. —una de las viejas y recurrentes cuestiones de la Unión Socialista desde el momento de su creación en 1923-Comorera y la Unió Socialista lograrian ir afirmando una confluencia triangular (Partit Català Proletari, Federación Catalana del PSOE y USC) que se iba a completar con el Partit Comunista de Catalunya. Éste había sido constituido con muchas dificultades en mayo de 1932 alrededor de Ramón Casanelles, Antonio del Barrio y Hilari Arlandis, también Pere Ardiaca, después de la ruptura de 1931 de Maurin y la Federación Comunista Catalana Balear con el PCE. La moderación del izquierdismo insurreccionalista inicial y el apoyo a la política frente populista, facilitó la confluencia de sus fuerzas sindicales con la UGT y finalmente la participación en el proceso de unificación que dirigía Comorera. Como es sabido, en julio de 1936, la rebelión militar aceleró la fijación de un comité de enlace entre los diversos grupos y la constitución del PSUC.

Las discrepancias de la Federación Comunista Catalano-Balear (creada en 1924 por Joaquín Maurín a partir de la experiencia de los comités sindicalistas revolucionarios) respecto de la dirección del PCE se agudizaron en el transcurso de los años de la Dictadura de Primo de Rivera y resultaron oficializadas en 1930. Por otro lado, existía desde el 2 de noviembre de 1928 un Partit Comunista Català, que había reunido trabajadores catalanistas estudiosos del marxismo autodidactas del Ateneu Enciclopèdic Popular (Jordi Arquer), junto a algunos hombres procedentes

20 Cf. el texto ya citado de Miquel CAmINAL (1984): Joan Comorera (catalanisme $i$ socialisme), 2 vols., Barcelona. También, la aportación de J. L. MaArín dentro de AAVV (1999): 75 aniversari. Unió Socialista de Catalunya. Barcelona. 
también de Estat Català (como Jaume Miravitlles o Martí Vilanova). A finales de 1930 la Federación y el PCC acordaron la unificación y crearon el Bloc Obrer i Camperol (noviembre de 1930). La cohesión del nuevo grupo resultó indirectamente fortalecida al divulgarse las tesis bolcheviques sobre la cuestión nacional y en especial el famoso texto de Stalin. La estrategia y consolidación del BOC se basó en una actuación de corte vanguardista e intelectual que combinaba la polémica teórica en campos artísticos, literarios y políticos con una presencia más o menos sindicalista en el campo y aigunas ciudades como Lleida y Girona. A partir de 1933-1934, se abandonó la estrategia de radicalización del catalanismo (con el consiguiente abandono de algunos dirigentes como Jaume Miravitlles o Daniel Montserrat que pasaron a Esquerra) y sus esfuerzos se centraron en las tesis de la unidad obrera (cuando se impuso la opinión que se habían ya agotado las potencialidades revolucionarias de la pequeña burguesía y era ya inexcusable una dirección proletaria del proceso de transición hacia el socialismo. Andreu Nin, uno de los poquísimos dirigentes obreros españoles con un papel internacional destacado, miembro de la comisión ejecutiva de la Internacional Sindical Roja, se vio implicado en las disputas antiestalinistas de Trotski y al volver a Barcelona en 1931 no encontró fácil acomodo. Creó primero una Oposición Comunista de Izquierda, convertida a continuación en Izquierda Comunista, pequeño grupo que contó con un reducido núcleo de fieles (J. Andrade, Narcis Molins i Fàbregas). En 1933-1934 no quisieron entrar en el PSOE y rompieron abiertamente con Trotski. Ello facilitó el entendimiento con el BOC y el 29 de septiembre de 1935 ambos partidos se integraron en el Partit Obrer d'Unificació Marxista (POUM) ${ }^{21}$.

Una de las novedades derivadas de este doble proceso de unificación de partidos marxistas - la que llevó al PSUC con presencia destacada de grupos de tradición socialista y socialiberal y la que llevó al POUM con un mayor peso directo de la tradición comunista de referencia bolchevique- fue la formulación de un catalanismo de lenguaje y vocabulario mar-

21 Entre la diversa e irregular bibliografia existente sobre los diversos grupos y personalidades marxistas en Cataluña, hay que destacar en especial Roger ARnau (1974): Marxisme català i quëstió nacional catalana, 1930-1936. París; Francesc Bonamusa (1974 y 1977): El Bloc Obrer i Camperol (1930-1932). Barcelona, y Andreu Nin y el movimiento comunista en España (1930-1937). Barcelona; Pelai PAGES (1975): Andreu Nin: su evolución politica (1911-1937). Madrid; Josep Lluis MARTIN (1977): Els origenes del Partit Socialista Unificat de Catalunya (1930-1936), Barcelona; Albert BaLCELLS (1977): Marxismo y catalanismo 1930-1936, Barcelona; Ricard ViNYES (1983): La Catalunya internacional. El frontpopulisme en l'exemple català, Barcelona; Antoni MONREAL (1984): El pensamiento politico de Joaquin Maurin. Barcelona; AAVV (1994): Andreu Nin; AAVV (1998): Andreu Nin i el socialisme, Barcelona 
xista, que situaba en unos parámetros algo alejados de las formulaciones tradicionales socialistas del PSOE el debate sobre la realidad nacional de Cataluña y, también, lejos de las discusiones más usuales de contexto liberaldemocrático.

\section{CATALANISMO NACIONALISTA Y SOCIALDEMOCRACIA}

A principios de siglo, lo vimos ya en parte, permanecían activos dos grandes ámbitos del pensamiento de izquierdas ${ }^{22}$. En primer lugar habia que tener en cuenta el protagonismo renovador del modernismo, que se manifestaba a través de revistas intelectualizadas como "L'Avenç", "Catalònia" o "Joventut» y, también, en las páginas del diario ya mencionado de «El Poble Català». Implicaba una respuesta al positivismo evolucionista más determinista y el descubrimiento - neófito- de Nietzsche, Shopenhauer y Stirner. De ahí que pudiese encontrar acercamientos y proximidades con reacciones similares que provenían de la cultura de la derecha (por ejemplo, en un caso convertido ya en tópico, Joan Maragall). De todas formas existían otros autores y hombres que - con mayor o menor patetismo- mantenían puentes con la vieja modernidad positivista del ochocientos. Era el caso de Pompeu Gener y el más joven Jaume Brossa. En conjunto, esta línea partía de la tradición del catalanismo progresista y el republicanismo federal del ochocientos.

Oscurecida en parte -más por la historiografía posterior que no por la realidad social de la época- existía una segunda línea de pensamiento de izquierdas, la del liberalismo relacionado y abierto al reformismo institucionista español. Se trataba en este caso de una cultura liberal-progresista de izquierdas que se había ido forjando al margen del republicanismo federal y en gran medida como alternativa al mismo. Se trataba de una izquierda que podía sentirse identificada con "La Publicidad", "El Liberal", y poco después "El Progreso». Tuvo una especial incidencia en la introducción de las nuevas disciplinas de ciencias sociales (sociología, antropología, psicología social, criminología, higienismo). Destacó en este sentido un hombre hoy muy olvidado, Santiago Valentí Camp, que animó múltiple empresas editoriales como la "Biblioteca Moderna de Ciencias Sociales" de la casa de Antonio López, que publicó textos de Altamira,

22 He desarrollado este tema con una cierta amplitud en "Transicions i canvi de segle", en Pere Gabriel, dir. (1995): História de la Cultura Catalana, vol. VI, El modernisme 1890-1906, Barcelona. 
Posada, Unamuno - su famoso libro En torno al casticismo-, Pedro G. Dorado, Adolfo A. Buylla, etc. También, la «Biblioteca Sociológica Internacional» (de la casa Heinrich) con más de 70 títulos editados entre 1904 y 1909. Fue él, en fin, quien lanzó unos "Manuales Soler», a modo de colección enciclopédica que incluía desde textos de ciencias aplicadas hasta síntesis y ensayos de la nuevas disciplinas.

Aceptando las muchas simplificaciones de cualquier esquematismo, es clara la incidencia de los primeros en la formulación de un catalanismo de izquierdas y la afirmación más genérica española del pensamiento de los segundos, los cuales no dudarían en identificar el catalanismo con el conservadurismo y la reacción.

Debemos añadir la presencia en la izquierda catalana de principios de siglo del eclecticismo anarquista. Éste intervenía en espacios más o menos ajenos como los de la Escuela Moderna de Ferrer i Guardia (otro ex-republicano progresista que se incluye en la tradición del liberalismo progresista de corte institucionista), que editó una obra considerable a través de las Publicaciones de la Escuela Moderna (donde estaban codo con codo Anselmo Lorenzo y Cristóbal Litran). Pero impulsada asimismo una serie de aventuras editoriales de divulgación plebeya de aquella cultura liberal-progresista, a la que simplemente daba lecturas y tintes anarquizantes. La editorial Granada que pasó luego a denominarse Atlande editó en especial una colección "Los Pequeños Grandes Libros" y resistió - lo que no era nada desdeñable - el empuje de las ediciones de la casa Sempere de Valencia ( $\sin$ competencia posible en el campo de las ediciones de masas de la izquierda). Los de GranadaAtlante publicaron mucho pensamiento anarquista clásico y cosmopolita (Proudhon, Bakunin, Kropotkin, Reclus, Grave, Malato, Malatesta, Gori) y las nuevas elaboraciones francesas del sindicalismo revolucionario y el antimilitarismo (Hervé, Hamon, Richard), al lado de textos de los grandes nombres de la filosofía social, el positivismo y el anticlericalismo del ochocientos (Darwin, Spencer, Novicow, Haeckel, Littré, Zola, Flammarion, Renan), que combinaron con los libros de la reacción individualista (Shopenhauer, Nietzsche, Maeterlink). Incluyeron también algunos nombres del socialismo marxista (Guesde, Engels, Lafargue, Vandervelde, Bebel).

Todo este mundo, que se había visto implicado en la campaña de protesta y revisión del proceso de Montjuic, se mantuvo vivo al menos hasta los años del bloque de izquierdas antimaurista y la semana trágica de 1909. Con menor fuelle, se mantuve activo hasta los años de la primera guerra mundial. 
Por su parte, la alternativa plebeya del modernismo catalanista fue mucho más débil — significativamente, a diferencia de lo que había sucedido en los años setenta y ochenta del siglo xix-, incapaz de frenar en la izquierda la hegemonia de la cultura liberal-progresista. De todas formas existió con alguna incidencia en determinados y pequeños núcleos anarquistas y obreros autodidactas. Sus mejores ejemplos fueron los grupos del Foc Nou y L'Avenir animados por el tipógrafo Felip Cortiella y el lampista Josep Mas-Gomery. Cuando llegó el momento de la dispersión y el reflujo, sólo hallaron cobijo en "El Diluvio" —así Jaume Brossa- (y no en "La Publicidad" o "El Progreso").

El impacto en todos los campos de la vida social generado por la guerra europea de 1914 iba a favorecer la aparición renovada de un catalanismo liberal que iba a marcar profundamente el catalanismo de izquierdas de los años treinta. Surgió, al mismo tiempo, del debate abierto a lo largo de los años veinte sobre la crisis del parlamentarismo y la democracia liberal y de la nueva definición nacionalista del catalanismo. Tuvo asimismo tonos influidos por la aparición de un pensamiento socialdemócrata y contó, en el límite con la irrupción de grupos de vanguardia comunista y anarquista individualista.

El pensamiento de la izquierda, lógicamente, recibió el impacto, muy abrupto y escandaloso, de la crisis generada por la primera guerra mundial y la revolución rusa. En Cataluña, como en el resto de España, la cultura de la izquierda se encontró ante la necesidad de una reformulación capaz de dar respuesta a crisis del estado liberal y del pariamentarismo liberal ${ }^{23}$. Un estado y un parlamento que parecian no tener respuestas ante la agitación y la movilización política de las masas y muy en especial la clase obrera.

En este punto, iba a ser especialmente notorio en Cataluña el llamado debate sobre las dictaduras y el fascismo que abrió Francesc Cambó a través de obras como Entorn del feixisme italià. Meditacions i comentaris sobre problemes de la política contemporània (1924) y más adelante Las dictadures (1929). Su argumentación (la de la Lliga) establecía una estrecha relación entre cultura cívica de las masas y viabilidad de la democracia (sólo algunos pueblos - cultos- merecian un verdadero parlamentarismo). Las dictaduras por tanto eran regímenes que tendian a instalarse en sociedades atrasadas. El fascismo no era, sino una dictadura con ideo-

23 Cf. Pere Gabriel (1997): "Reflexions polítiques davant la crisi dels estats liberals", en Pere GABRIEL (dir.): História de la Cultura Catalana. vol. VIII. Primeres Avantguardes, 1918-1930, Barcelona. 
logía: la respuesta negativa contra el parlamentarismo y la vieja politica y respuesta positiva de defensa del patriotismo (el imperialismo), la autoridad y el estado. Era en el fondo una adaptación del estado y el poder a las exigencias de las nuevas realidades y exigencias de aquellas masas. La argumentación de aquel catalanismo de derechas se completaba a través de una defensa y replanteamiento de la autonomía y profesionalidad del mundo de la política y los políticos, como hizo Lluís Duran i Ventosa con su libro sobre Los políticos (1927). Eran indispensables, aunque el parlamento liberal no habia sido a la postre una buena escuela.

Ante aquella crisis del parlamentarismo liberal se produjeron multitud de respuestas. Un segundo grupo se movió en un contexto de defensa del liberalismo. Por aquí pueden situarse algunos liberales dinásticos (en especial el canalejista Roig i Bergadà ${ }^{24}$ ) y sobre todo el liberalismo republicano y catalanista de Rovira i Virigili y los hombres de Acció Catalana (Nicolau d'Olwer, Hurtado, etc.) ${ }^{25}$. Con lógicos matices, todos ellos coincidian en definir la democracia como el funcionamiento de mecanismos pacíficos de acceso a! poder, proclamaban la viabilidad del liberalismo democrático (y usaban mucho Benedetto Croce) y pretendian situarse ideológicamente en el "centro, en un punto medio entre los extremismos de la derecha (el fascismo) y de la izquierda (las masas y el bolchevismo). Eran, según ellos, esenciales el sufragio universal, los partidos políticos y el patriotismo. Las grandes conmociones - así la guerra- provocaban el afloramiento de las fuerzas instintivas (autoritarias o anarquizantes), pero la normalidad debia devolver el papel fundamental al partido liberal (que no era sino "el partido de la cultura»). Ciertamente el liberalismo habia perdido las masas, pero era un partido de gente selecta. Además, al haber sabido rectificar el manchesterianismo económico de hecho podía acercarse al socialismo reformista.

Hizo su aparición en el debate, por último, con cierto estrépito, el marxismo bolchevizante. Nin (Les dictadures dels nostres dies, 1930) y Maurín (Los hombres de la Dictadura, 1930). Al margen de su rigidez interpretativa, Nin rompió los parámetros en los que se habia situado la discusión: según él, tanto el fascismo como el parlamentarismo liberal no eran sino opciones de dominio y control de la burguesía - dictaduras de la burguesía- frente a las cuales la verdadera democracia —el poder de la mayoría- no podía ser sino la dictadura del proletariado.

24 Cf. Doctrina liberal y democrática, Barcelona, 1930.

25 Cf., en especial, Antoni RoviRa VIRGILI, Defensa de la democràcia, Barcelona, 1930, y Lluís Nicolau d'Olwer, La lliçò de la Dictadura, Barcelona, 1931. 
En conjunto fue un debate en el que sólo algunos parecian defender la democracia (los liberales). Pero fue este debate y la reflexión ante la crisis del parlamentarismo que iba a permitir en el futuro la aproximación de este grupo liberal catalanista al movimiento de Esquerra Republicana.

El segundo gran fenómeno de impacto llegó de la mano de la definición nacionalista del catalanismo (la afirmación del catalanismo incluyó ya de forma mayoritaria la definición nacional de Cataluña). La nueva definición hegemónica se produjo ante el doble reto de renovar la integración populista de las masas urbanas y de intentar un canje dentro de la realidad de un estado liberal español en crisis. Aquella definición nacionalista fue formulada según pautas conservadoras. Éstas resultaron ahora popularizadas y aceptadas (al menos como punto de partida de la reflexión) por todos y también por la izquierda. Fue uno de los efectos indirectos de la Dictadura de Primo de Rivera. Con ello, el trabazón ochocentista entre federalismo, catalanismo y reivindicación social pareció romperse. En la nueva situación el federalismo social pasó a ser fundamentalmente un patrimonio de los anarquistas y anarcosindicalistas.

Símbolo de los nuevos tiempos, Prat de la Riba, muerto en 1917, pasó a ser un referente inexcusable. Algunos, como Jaume Bofill i Mates, para profundizar en el contenido organicista y corporativista, católico, de la definición nacional patriana. Otros, como Joan Estelrich, para "superar" la vieja oposición entre las concepciones liberal y conservadora-historicista, aceptando introducir en el tronco nacional esencial la acción de libre decisión y voluntad de los ciudadanos. El razonamiento en este sentido le llevaba a afirmar, por ejemplo, "los derechos de los catalanes son de siete siglos anteriores a los derechos del hombre. Pero sólo los derechos del hombre son la garantía futura de los derechos de los catalanes ${ }^{26}$. Otros autores en fin, como Antoni Rovira i Virgili, partían de una tradición federal e intentaban explícitamente la conciliación entre el pensamiento patriano y el nacionalismo liberal. Así, la conciencia nacional era en cualquier caso un elemento esencial de la nación y si, dentro del catalanismo había habido y había una derecha y una izquierda, podían distinguirse un pensamiento conservador y uno liberal, toda nación tenía derecho desde la construcción de una fórmula espiritual común, un alma nacional, a un estado independiente ${ }^{27}$. Como voy argumentando, globalmente ahora todo el

26 Cl. Joan Estelfich, Catalunya endins, Barcelona, 1930, págs. 31-32. He traducido el texto al castellano.

Algunos de estos argumentos aparecieron ya en el prólogo de Antoni RoviRA I VIRGILI a una edición de textos de PRAT DE LA RIBA, Nacionalisme, Barcelona, 1918, y en Polèmica sobre $P i$ i Margall, Barcelona, 1928, contra Duran i Ventosa y Josep PLA. La obra de Rovira es muy extensa. 
catalanismo era nacionalista. El cualificativo regionalista pasó a tener un tono peyorativo, sospechoso de españolista, aplicado como arma arrojadiza contra la Lliga y Cambó.

De todas formas, era claro a pesar de esta definición nacionalista, que el catalanismo debía responder al reto del encaje dentro de la realidad española. La discusión había surgido ya en tiempos de la crisis de la Lliga y el fracaso del proyecto de autonomía de 1918-1919. Rebrotó de manera intensa ante la perspectiva postdictatorial de los últimos años veinte. Una argumentación más o menos compartida dentro del catalanismo liberal era la que debía contarse con un programa de autogobierno capaz de afirmar la conciencia nacional. Era necesaria y cada vez más urgente la famosa consigna de "Catalunya endins". Pero toda nación tenía una misión que cumplir y debia, por tanto, afirmar un papel hacia el exterior (el imperialismo). A partir de todo ello el encaje espariol podía concretarse en tres grandes opciones.

Según algunos, era necesaria una división "nacional» de la península basada en las realidades de Castilla, Basconia, Portugal —que incluía la realidad gallega--, Andalucía y, claro está, Cataluña. A partir de la división podía ponerse en práctica un "nacionalismo federador» que impulsarían, por un lado Cataluña y la mediterráneidad y por el otro Portugal y el atlantismo. Con ello se forzaría la resituación de Castilla y el españolismo no sería ya un exclusivo patrimonio del castellanismo. Era ésta la opinión, en especial de un famoso grupo intelectual en el que participaba activamente el poeta Jospe Vicenç Foix, el llamado grupo "Monitor", muy activo en 1921-1923 ${ }^{28}$. A notar que en este caso se rechazaba tanto el "separatismo separador" - que se atribuía a Macià- como el "iberismo españolista» de Francesc Cambó.

En segundo lugar, había la posibilidad de aceptar, con matices, el iberismo camboniano, que reconocía una realidad ibérico/española y, por tanto, un estado español si éste reconocía la personalidad catalana. Fue lo que procuró la ortodoxia derivada de Acción Catalana y Jaume Bofill $i$ Mates. Según ésta, el debate debía situarse en un marco europeo y atribuir a una nueva España democrática la defensa en el contexto europeo del ideal ibérico. La opción republicana era la única garantía de democra-

Puede consultarse la buena relación preparada por su hija, Teresa RoviRA, en Homenatge a Antoni Rovira i Virgili. Barcelona, 1980.

28 Una análisis sobre la obra de Folx i "Monitor" en el marco de las relaciones establecidas con Giménez CABALleRo y "La Gaceta Literaria», on E. UCELAY-DA CAL, "Vanguardia, fascismo y la interacción entre nacionalismo español y catalán", en Justo G. BERAMENDI y Ramón MAiz, comps., Los nacionalismos en la España de ia II República, Madrid, 1991. 
cia para España y para Cataluña, en uso de una «autodeterminación renovadora", sólo cabía el entendimiento con la España liberal y asumir su liderazgo. Si Cataluña no inspiraba la democracia española, resultaría deformada por la misma. En este sentido, si Cataluña no era imperialista, sería provinciana ${ }^{29}$.

El catalanismo de izquierdas iba a incorporar dosis importantes de pensamiento socialdemócrata, aunque ello no significase traspasar determinados y claros límites respecto del alcance social de aquel liberalismo democrático catalán. En Cataluña, el pensamiento socialdemócrata tenía importantes raíces ochocentistas que se situaban en determinados sectores del republicanismo federal, el sindicalismo reformista y pro-republicano de la Primera Internacional y el socialismo reformista de "El Obrero". También podían encontrarse huellas del mismo en la intelectualidad regeneracionista del cambio de siglo. De todas formas la primera configuración global no se produjo hasta los años veinte. Muy intelectualizado, conectó entonces con las teorizaciones coetáneas europeas. Intervinieron, destacadamente, hombres que provenían del regeneracionismo finisecular como Pere Coromines (1870-1939) y Gabriel Alomar (1873-1941), militantes del PSOE y el socialismo catalán como Antonii Fabra Ribas (1879-1958) y Sosep Recasens i Mercadé (1883-1954), dirigentes de la Unión Socialista de Catalunya como Manuel Serra i Moret (1883-1963) y Rafael Campalans (1887-1933) $y$, en fin, los miembros del grupo republicano de izquierdas de "L'Opinión" que encabezaba Joan Lluhí i Vallecà (1894-1944).

La característica más relevante de aquel pensamiento socialdemócrata era que, partiendo de una genérica aspiración a la socialización de los medios de producción y la riqueza (la sociedad socialista), creía en la fundamentalidad de los valores de la democracia, negándose a considerar que ésta fuera sólo un régimen político transitorio y particular de la burguesía (como hacían, desde posiciones distintas, los comunistas, los anarcosindicalistas bolchevizantes y muchos socialistas de izquierda del momento). En este contexto el socialismo se convertía no ya el programa de un partido ni una simple propuesta de organización económica de la sociedad, sino una concepción filosófica. Era un «ideal

29 En el debate constitucionalista intervinieron notablemente CAMzó, con Per la concòrdia (1930) y BOFILL I MATES, con L'altra concòrdia. Per una revisió del problema català: la solució liberal i democràtica (1930). De todas formas el llamado "pleito constitucional» contó con muchisimos actores: Valls I Taberner, Tallada, Estelrich, Folguera, Cardó, Cases I Carbó, Soldev!la, Gonçal oe Reparaz, etc. N. Nart y M. Rubiò I Turudi, en Estat Espanyol, S.A. (1930) propusieron directamente en lugar de una "concordia" una solución de "conveniencia" basada en el interés mutuo. 
supremo de perfección social», como afirmaba Recasens en un texto muy representativo titulado Què és socialisme? (1931). La democracia, además del interés más o menos táctico que tenía para que los obreros pudiesen hacer valer su fuerza e influencia, era la condición indispensable de construcción del socialismo desde la civilidad. El resultado era un programa de socialismo evolutivo, que se situaba en posiciones intermedias y liberales, basado en el ejercicio de la democracia (las masas debían ser entrenadas en las funciones de la ciudadania). En palabras de Serra i Moret:

"El cami que tots escolliriem, el cami de l'evolució sossegada i racional, és interdit per cada costat [los partidarios de las dictaduras negra o roja]. Però ens correspon a nosaltres, socialistes, portar als esperits rebels, als esperits dignes, la forma eucaristica de l'humanisme trascendent (...) per tal que (...) facin profitosa per a tots aquesta "Iluita final", ${ }^{30}$.

En este marco, tanto el marxismo como el obrerismo dejaban de ser unos componentes rígidos y exclusivos de la definición socialista. A pesar del respeto que ies merecía y de los reiterados esfuerzos de su lectura de la obra de Marx, se podía ser un perfecto socialista sin ser marxista. Dentro del socialismo cabían, según se decía, todos los hombres de ideales generosos, justicieros, de altitud de miras y verdaderamente democráticos. Como podemos ver, todo este socialismo democrático catalán asumía en buena medida la cultura de izquierdas de tradición republicana federal y librepensadora. Esto diferenciaba acusadamente el socialismo catalán del socialismo de los dirigentes socialistas del PSOE que habian asimilado más profundamente el discurso del marxismo ochocentista y guesdista.

Fueron explícitas las deudas respecto del pensamiento socialista europeo del momento. Dominaba la atracción por el socialismo británico, cualificado como «socialismo liberal»: los fabianos Sidney Webb y su mujer Beatrice Potter, H. G. Wells, B. Shaw y el laborista J. Ramsay MacDonald, conocidos y muy divulgados especialmente por Serra i Moret y Fabra Ribas. Permitía alimentar la idea de un movimiento de intelectuales que impregnaría capilarmente la sociedad catalana en detrimento de las rigideces y poco alcance de las políticas de partido. Otro de los referentes básicos era Jean Jaurès, que se oponía a Guesde en cuanto, según decían, habían liberado el marxismo y el socialismo francés de los determinismos

30 Cf. el "Pròleg" de SERra I MOREt al libro citado de J. RECASEnS, Què és socialisme?, Reus, 1931, pág. 10. 
económicos y había sabido recoger positivamente toda la tradición política republicana democrática y popular. Algo más coyunturalmente, también se dedicó una atención destacada a algunas obras del socialista belga Henri de Man (Zur Psychologie des Sozialismus, de 1926, popularizado a partir de su versión frances que llevó por título Au delà du marxisme). Finalmente, estaba la relación concreta con los directores y los documentos de la reconstituida Internacional Socialista.

La afirmación de un pensamiento socialdemócrata en Cataluña tuvo también como uno de sus elementos definitorios la asunción de la realidad nacional catalana. Unas pautas básicas habian ya sido fijadas por Gabriel Alomar antes de la guerra europea, con la serie de artículos Armonización de la corriente socialista con la nacionalista (1902-1907, 1916) y las conferencias Negacions $i$ afirmacions del catalanisme y $\mathrm{Ca}$ talanisme socialista de 1910. Alomar supeditaba la plena construcción de la nación a la constitución como clase nacional de la clase obrera catalana. Esto sólo podía llegar a través del socialismo y la lucha de una nueva izquierda que fuera capaz de recoger los componentes fundamentales de la "ciudad de las ideas" (catalanismo, civismo -opuesto al ruralismo- y obrerismo). Después de haber sido identificado con la riqueza y con la clase media, era necesario ahora que el catalanismo lograra un tercer estadio (¿quién mejor que los obreros podian representar toda Cataluña?).

En los años de la guerra y la campaña de autonomía de 1918-1919, la Federación Socialista de Cataluña (con Recasens, con Nin) consiguió a pesar de unas fuertes reticencias y gracias al apoyo de todas formas de Julián Besteiro que el PSOE aceptase la perspectiva de una Confederación Republicana de Nacionalidades Ibéricas. La reacción posterior que lideró Indalecio Prieto y Antoni Fabra Ribas, que identificó cualquier tipo de nacionalismo con las afirmaciones de raza y expansionismo guerrero, provocó de rebote un esfuerzo importante de clarificación del catalanismo socialdemócrata y, en definitiva, facilitó la constitución de la Unió Socialista de Catalunya el mismo 1923. Destacadamente, Campalans en El socialisme i el problema de Catalunya (1923) se esforzó en diferenciar el nacionalismo agresivo y el derecho a no ser absorbidos y el desplegamiento libre y completo de las pequeñas nacionalidades. Advirtió, además, que el internacionalismo sólo tomaría su más pleno sentido cuando pudiese susientarse en las diversas nacionalidades afirmadas por los obreros. En una misma dirección, Serra i Moret mantenía que el verdadero lugar de encuentro de los socialistas españoles y los catalanes habia de ser, algún día (cuando Cataluña se separase de España) la Internacional Socialista. 
Lo hemos ido diciendo de manera dispersa e implícita a lo largo de la explicación: era general la voluntad de hacer corresponder la dirección de la vida política y la vida social catalanas a una minoría selecta y culta, en gran medida identificada con la intelectualidad y la profesionalidad técnica. En este punto coincidían, desde las más diversas posiciones, muchos de los protagonistas del pensamiento corporativista, el liberal y buena parte del socialdemócrata.

En Bofill y el mundo de nacionalismo de Acció Catalana, había la conciencia de la contradicción entre el interclasismo proclamado de la nación como a tal y la persistencia de los conflictos sociales internos, así como del hecho que la movilización nacional afectada a sectores aún reducidos de la población. Para resolverla, se apelaba precisamente al concepto de «minoría selecta»: el derecho al ejercicio de la autodeterminación nacional se justificaba en la medida que había una minoría culta que lo pedía y podia garantizar el posterior autogobierno. A medida que el pueblo actuase democráticamente el gobierno de la minoría había de saber resignar la dirección.

Por su lado, los socialdemócratas consideraban que la construcción del socialismo no era sólo una misión histórica de la clase obrera, sino el fruto de diálogo entre los obreros y los intelectuales. En palabras de Rafael Campalans de 1922:

"És solament en l'amistat amb els intel. lectuals que la democràcia podrà fer triomfar la revolució. Insensats els qui creuen que la multitud pot crear res, pot governar el pais ${ }^{31}$.

Todo ello era consecuente con la primacia otorgada a la cultura y la educación en el proceso que debia llevar a la emancipación social, cuestión ésta que habia de dar lugar al último libro, emblemático, del mismo Campalans, Política vol dir pedagogia. Manual de socialisme català (1933) ${ }^{32}$

Desde siempre, ya en el ochocientos, en el mundo político catalán había sido muy alto el protagonismo de los profesionales y los intelectuales (autodidactas o no). Lo nuevo fue la justificación teorizada y

${ }^{31}$ Cf. Els problemes de l'educació del poble, Barceloria, 1922. Conferencia pronunciada el 19 de octubre de 1922 en el Ateneu Enciclopèdic Popular de Barcelona.

${ }_{32}$ Sobre Campalans, cf. Albert BALCELLS, Rajael Campalans, socialisme català. Biografia $i$ textos, Barcelona, 1985. 
explícita del fenómeno. Ciertamente las coincidencias no impedían la existencia de algunas diferencias respecto de los objetivos de la intervención y dirección social que se autoatribuían. En cualquier caso, el tema venía a poner de manifiesto los muchos límites y al mismo tiempo la gran ambición tanto del liberalismo de buena parte del nacionalismo catalán, como del socialismo democrático, empañados ambos en ejercer una muy difícil hegemonía sobre el conjunto de la población catalana. Lamentablemente, muy pronto, el estallido de la guerra y el posterior triunfo franquista deshicieron dramáticamente sus ilusiones y situaron los debates en otro contexto, aunque de algún modo la superación democrática más reciente pueda y quizá deba reencontrar algo de aquellos hombres y aquellos intentos. 